\title{
Albanian Challenges towards an Efficient Pension System
}

\author{
Olgerta Idrizi \\ Faculty of Economy, Mediterranean University, Albania \\ Besa Shahini \\ Faculty of Economy University of Tirana, Albania
}

\section{Abstract}

Pensions' reform in most Western, Central and Eastern European countries is one of the most important topics relevant for their future development. The main objective of this study is to assist in predicting the future of the pension scheme in Albania through actuarial projections related to demographic structure, unemployment, number of contributors and beneficiaries. Through this study, we intended to predict what would be the financial effect of two options. First, we investigate the likely outcome if Albania continues with the same scheme as currently used. Second, we investigate the likely outcome when a new contributory scheme is being implemented. The methodology used for implementing the actuarial model is based on the construction of the population projections using the RUP system (Rural Urban Projection), a system developed by the Census Bureau of the United States of America, while the economic performance forecasts, i.e.: GDP, inflation rate, unemployment rate or expected indexation of wages and pensions, are be sourced by the Albanian Ministry of Finance and the International Monetary Fund. The study concludes and recommends some of the steps for reforming the pension scheme in Albania based on the experience of other countries and the likely financial effect to the state budget in case of the implementation of the new scheme.

Keywords: Pensions, predicting, actuarial model, Inflation rate, demographic structure, unemployment etc.

JEL classification: C 15

\section{Introduction}

Traditionally World Bank offers during all its literature review a three-pillar system referring to the pension system (Xhumari, 2000). However, going through a detailed observation of the pension system throughout the countries all over the world and the efforts undertaken to build a sustainable pension system, it is considered as interesting to add two extra pillars to then old literature and discuss a five-pillar pension system (Lama, 2008). The zero pillar: has to do with the benefits associated with poverty reduction. Retirement payments are made for persons who have reached retirement age but have not contributed during their lifetime because they did not work or because they did not want to contribute to pension schemes.

- First pillar: A mandated, unfunded and publicly managed Defined Benefit system. This pillar, mainly guarantees the protection of the elderly from poverty, which is part of the redistributive function of the state. This scheme is called generation relationship, as current contributors pay to get benefits those citizens who are currently retired. This is the so-called model of Pay as You Go, the one that Albania is applying. 
- Second pillar: A mandated, funded and privately managed Defined Contribution system. This pillar is a combination between a private scheme and the public pension system and is based on capitalization or redistribution, but it should to be clearly separated from the first pillar. Under this scheme, part of the mandatory contribution will be administered by the public scheme Pay as you go (current scheme: solidarity between generations), which will guarantee a basic pension while the rest will be administered by private companies. These companies will pay the pension when the retirement age will arrive, based on the paid compulsory contribution along with the gain realized over the years.

- Third pillar: A voluntary funded and privately managed retirement system. This means that all the people who aspire for higher pensions than normal can become part of these schemes. The private pension scheme is still an area to be explored and needs further reforms in Albania to be very effective. Under this scheme, the citizens are free to contribute to this scheme, which is completely independent, and not under the state control.

- Fourth pillar: This is also a non-funded system. Here, we find more social aspects of the scheme, such as family support, health care, and others.

The right to receive a pension in one of these schemes belongs to everybody who has reached retirement age. The experience of recent decades has shown that many countries are transforming pension systems from mono-pillar version to the multiple one. Multiple-pillar pension systems are more appropriate to meet the goals and objectives that a pension scheme should have (Blake, 1992). The most important objective of the pension system is to reduce old-age poverty and ensure a level of living close to what an individual had while working. The multi-pillar system better absorbs the gap among population groups (Baldwin, 2009).

In many Western European countries, the term "second pillar" is often associated with the supplementary pension schemes set up under collective labour agreements. Looking at the trends in pension reform in Central European countries in transition, like Poland and Hungary, there was a shift from Pay as You Go (PAYG) to funding pension schemes (Deacon et al., 2005) . Under the assistance of the World Bank, this trend was followed by Western Balkan countries: Croatia, FYROM and Kosovo. On the other side, the International Labour Organization (ILO) is supporting the existing public PAYG systems, which would be reformed to face the complex challenges (ILO, 2011). The Czech Republic was continuing reforming the PAYG pension system, as well as the other Western Balkans, including Albania.

Reforms of the PAYG system started in 1993 resulted not so effective and efficient, so the pension reform is under the main priorities of the Government (Schwarz, 2006). The main intervention in this sector was undertaken in 2002 and the last one in 2014. The strategic objective of the Government is to develop the second and the third pillars of pension system, as the first pillar is not attractive anymore, due to many changes in Albanian context through year (Ministry of social wellbeing and youth, 2014). Based on the solidarity among generations characteristic, the PAYG system provides immediate benefits for retired people, but creates little or no contributions to those who are of working age. For this reason, the unfinanced pension system PAYG is vulnerable to risk. PAYG scheme works well when the rate of increase in labour force participation is the same as the rate of natural growth of the population.

The challenges of this pension system depend on the country's demographic and economic developments (Holzmann et al., 2008):

Projections in many parts of the world, including in Albania, show that in the near future the percentage of working age population will decrease, compared to the percentage of pensioners (Eurostat, 2013). These demographic changes are the result 
of the retirement of the generation of people born in the post-World War II years (considered as the baby boom years) as well as the increase in life expectancy due to the development of medicine and changes in lifestyle and diet foodstuffs (Centre for Research and Policy Making, 2005). This phenomenon is called "population aging". The aging of the population is accompanied by an increase in the fiscal burden that the government has to afford to pay for pensions (IOM - Country profile Albania, 2017).

The question is whether Albania is in the situation of population aging? According to the Institute of Statistics, the old age index (i.e. the population ratio 65 years and over with the total number of people) has increased from 8 percent in 2001 to 12 percent in the 2011 census (INSTAT, 2011). Nowadays, $7.9 \%$ of the whole population is over 65 years old in 2017, and $9.3 \%$ is foreseen in 2031 (INSTAT, 2018).

In addition, there has been a drop in the rate of replacement that is the ratio of the population under the age of 15 to the total population. Therefore, the replacement rate from $29 \%$ in 2001 was down to $21 \%$. As far as fertility indicators are concerned, we can say that the fertility rate of 2.3 children per woman in 2001 has decreased to 1.7 in 2011. This is due to the continuing decrease in the number of births, a phenomenon that is already present in Albania and we should be prepared to face the problem that accompanies it. Another important reason for accelerating the aging of the population has been immigration. Immigration as a phenomenon began after the 1990s and according to an assessment by the International Organization for Migration (IOM) Albania has had a migratory population rate for the last two decades by the highest number of people in the world. According to them, almost a quarter of the population has left the country and most of them were young men (IOM Migration in Albania country profile, 2016). The Albanian transition from a centralized economy to a free market led to the creation of private enterprises, which at the beginning were more focused on services and were small enterprises. The process of creating new jobs was at very low rates. According to the Labour Force Survey organized by INSTAT in 2017, the unemployment rate was $11 \%$. According to the same survey, the participation rate in the labour force for the population of 30-64 years old is $77 \%$, while the employment rate is $68.7 \%$. The labour market in Albania was also associated with a high degree of informality.

Table 1

Nr. of Employees and Contributors 2010-2016

\begin{tabular}{cccccccc}
\hline & 2010 & 2011 & 2012 & 2013 & 2014 & 2015 & 2016 \\
\hline $\begin{array}{c}\text { No. of Employees } \\
\text { (000) }\end{array}$ & 904 & 948 & 959 & 917 & 925 & 973 & 1043 \\
$\begin{array}{c}\text { No. of } \\
\text { Contributors(000) }\end{array}$ & 681.99 & 719.78 & 636.8 & 561.2 & 654.6 & 718.1 & 718.3 \\
\hline Source: INSTAT (2017); ISSH (2017) & & & & & & \\
\hline
\end{tabular}

Most of the employed do not declare themselves employed, thus avoiding social security payments. While in the case of employers declaring their employees, they tried to lower their salary by reducing the insurance premium. This is because by 2006 the amount of social security contributions was very high $29.9 \%$ of the salary from which $71.2 \%$ was paid by the employer. The Albanian government (2017) in 2006 lowered its contribution to $23.9 \%$. However, the Albanian labour market is characterized by a high degree of informality, which is reflected in the Table 1. In conclusion we can say that as a consequence of demographic changes, high migration rate, relatively high unemployment rate, low participation rate in labour 
force and high degree of informality in the labour market, number of contributors to the scheme of social insurance has dropped and consequently the income of the social security scheme. On the other hand, until now, almost every person who has reached retirement age during these years, since he worked in the period before the 1990s, has the right to receive a full or part pension, depending on the fact that how many years he/she has contributed.

So, the situation of the pension scheme today is characterized by a high number of beneficiaries and a low number of contributors. Since our pension scheme is a PAYG scheme, which means that the contributions of those currently working go to pay pensions to the beneficiaries of the scheme, the economic situation of the system is in risk. According to the SII, in the "Social Insurance Statistics" publication for 2017 the subsidy from the state budget is $1.83 \%$ of GDP, while it used to be high during three previous years as shown in Figure 1.

Figure 1

Ratio of Subsidy from the State Budget toward GDP

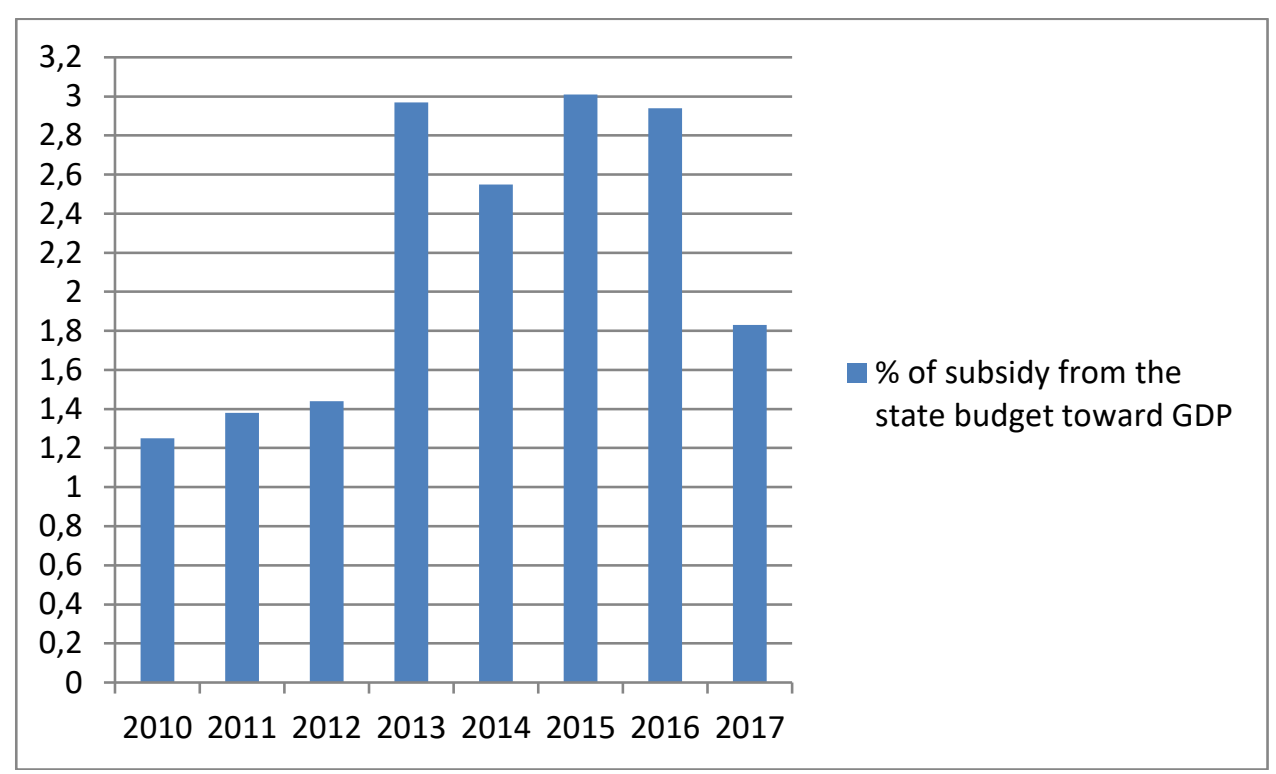

Source: ISSH (2017)

The Albanian Social Insurance Scheme is managed by the Social Insurance Institute, which is an independent public institution whose organization and operation is regulated by law. It is governed by the administrative council and the general director.

The Social Insurance Institute's mission is focused in the administration of the social security plan in general and to pension policies in particular, covering the population with social security elements in each country and time when it is proper, increasing so the number of contributors and collecting income from farmers' and volunteer contributions, improving efficiency in the management of social security funds, temporary free funds and reserve funds.

According to the Financial Regulation of ISI, it is allowed to borrow financial resources from one branch to another, against a defined interest rate. Interest-free borrowing is only allowed when it is approved by the Parliament in the ISSH's annual budget.

Some main statistical data through last three years are shown in table 2. 


\section{Table 2}

Financial situation- Total Incomes and its Components through Last Three Years in Albania

\begin{tabular}{|c|c|c|c|}
\hline & 2014 & 2015 & 2016 \\
\hline Income from contributions in total & 61.720 & 60.148 & 66.383 \\
\hline Compulsory scheme & 61.081 & 59.058 & 65.173 \\
\hline $\begin{array}{c}\text { Collected from GTD (General Directorate of } \\
\text { Taxation) }\end{array}$ & 52.464 & 56.473 & 62.692 \\
\hline Collected from SII (Social Insurance Institute) & 8.617 & 2.585 & 2.481 \\
\hline Supplementary scheme & 638 & 1.090 & 1.210 \\
\hline Contributions paid from State Budget (SB) & 6.751 & 5.794 & 5.022 \\
\hline For special categories & 3.291 & 3.533 & 3.712 \\
\hline For self-employed in Agriculture & 3.460 & 2.261 & 1.310 \\
\hline Percentage of GDP & 0.71 & 0.48 & 0.40 \\
\hline Financing of special programs from SB & 13.509 & 15.661 & 14.473 \\
\hline Special programs of government & 9.519 & 11.561 & 10.082 \\
\hline Suppl. scheme \& special treatments & 3.990 & 4.100 & 4.391 \\
\hline Percentage of GDP & 0.97 & 1.09 & 0.96 \\
\hline Total of Income & 81.980 & 81.604 & 85.878 \\
\hline Percentage of GDP & 5.88 & 5.69 & 5.72 \\
\hline Expenditure in total & 101.498 & 107.309 & 114.276 \\
\hline Benefit costs & 85.296 & 88.904 & 93.457 \\
\hline Special government programs & 9.633 & 11.497 & 13.687 \\
\hline Suppl. scheme \& special treatments & 4.707 & 4.892 & 4.973 \\
\hline Administrative costs & 1.862 & 2.016 & 2.159 \\
\hline Total of Outcome & 101.498 & 107.309 & 114.276 \\
\hline Percentage of GDP & 7.28 & 7.48 & 7.61 \\
\hline $\begin{array}{c}\text { Subsidy to cover the difference (Income- } \\
\text { Outcome) }\end{array}$ & $(19.518)$ & $(25.705)$ & $(28.398)$ \\
\hline Percentage of GDP & $(1.40)$ & $(1.79)$ & $(1.89)$ \\
\hline
\end{tabular}

Source: ISSH (2017)

\section{Some socio-economic projections to be considered}

Population projections are based on Population Census 2011 and Household Data Survey and they are used to predict the size and demographic structure of the population based on fertility, mortality and migration (Guxho, 2014). These projections will cover the period 2011-2050 and are built based on gender and age. There are several ways to build projections, but in this study, we will be based on the scenarios built by Guxho (2014) in order to predict the financial effects of the pension scheme.

Total Fertility Rate (TFR) is one of the most important components of population scenarios. The synthetic index of TFR has been decreased over years. The construction of TFR scenario is based on population data starting from 2001 according to age groups of five years and the methodology used is probabilistic scenarios of TFR. There are several methods to build TFR scenarios, but the one used is the Bayesian Scenario Model. Fertility scenarios are based on three scenarios: 1) Average scenarios: it is assumed that in 2050 TFR will be 1.75 2) Minimum scenarios: TFR will reach 1.25 level 3) Maximum scenarios: TFR will reach 2.25. 
Figure 2

Total Fertility Rates Scenarios

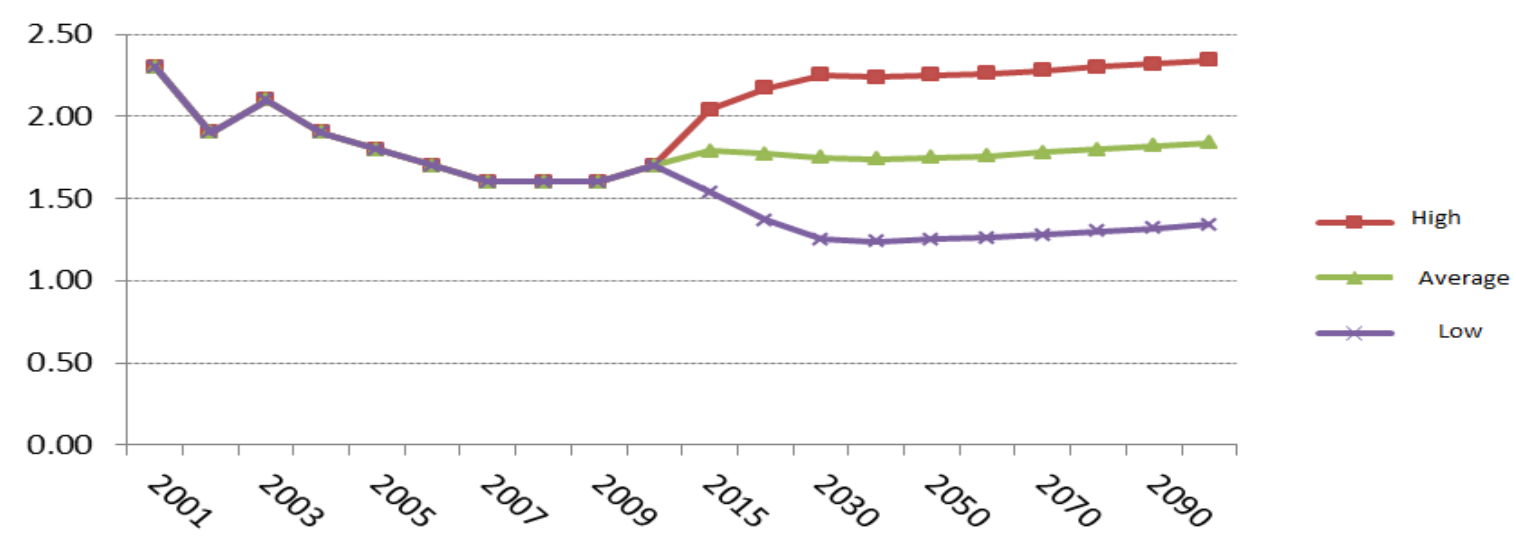

Source: Guxho (2014)

Figure No.2 refers to the projections of the fertility rates through years according to three scenarios. The projection, which is based on the trend of lifetime in the last 10 years, assumes that life expectancy will increase and will be 79 years old for males and 83 for females in 2051. Referring to the High scenario it will be 81 for males and 85 for females in 2051. Referring to the Low scenario, life expectancy will be 77 for males and 81 for females in 2051.

Figure 3

Life Longevity Projections

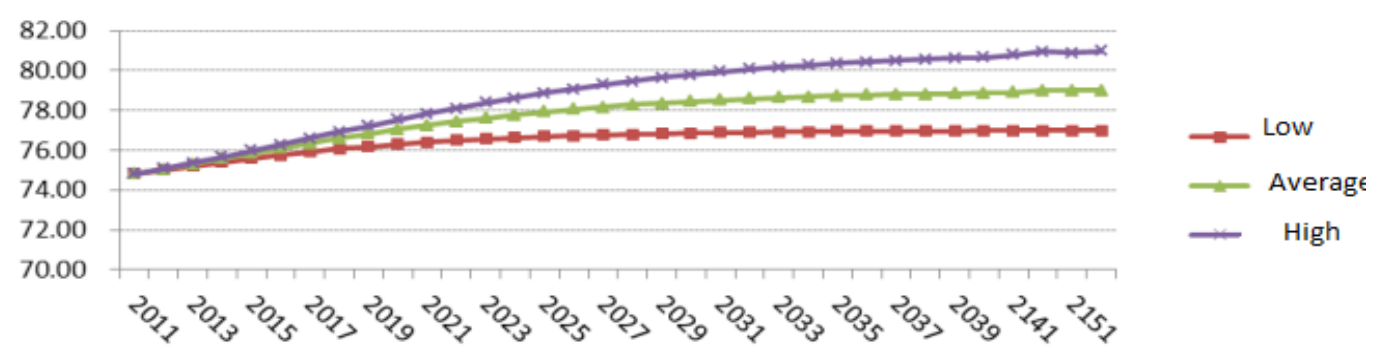

Source: Guxho (2014)

The RUP (Rural Urban Projection) program was used to calculate Mortality. For this, the life and gender tables were created. Starting from two life tables, which were taken from the 2001 and 2011 population census, interpolating the probability logs to death according to age groups, a new gender table was calculated in order to achieve the desired lifetime.

Figure No. 3 refers to the Life longevity projections through years according to three scenarios.

The migration phenomenon has always been present, but the rate of Albanian migration has changed. Migration projections are the most difficult predictions to be made, because detailed data is missing over the years. Figure No. 4 refers to Migration projections through years according to three scenarios.

Recent Census data showed a decline in the number of resident population from 3.1 million in 2001 to 2.8 million in 2011 , despite the positive natural growth (fertilitymortality) that we have had in these years. This decline has come because of immigration. 
ENTRENOVA 6-8, September 2018

Split, Croatia

Figure 4

Migration Projections

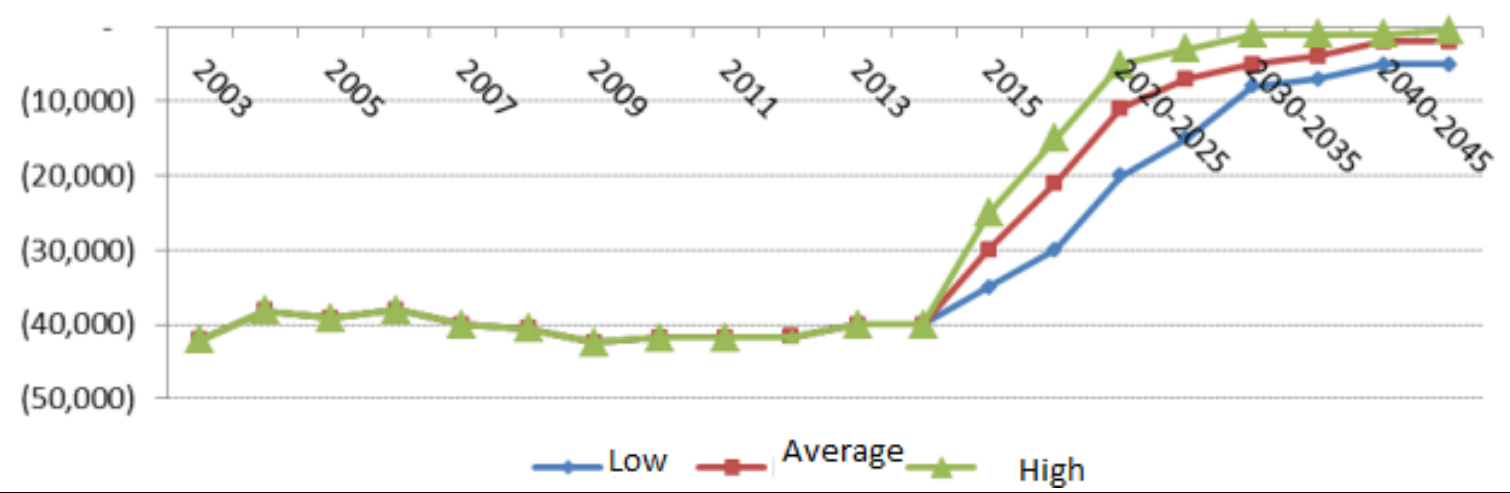

Source: Guxho (2014)

We have combined the mortality, Life longevity and migration projections for making the population projections, the low, Average and High variation consists in making the projections by referring to respectively the Low, Average and High Scenarios for each component.

Thus, according to the low variation, Albania's population will continue to decline by 2030 , where the population is expected to be around 2.47 million. According to the medium variant, the population decline will continue until 2025. According to the high variant, which is also the most optimistic variant, the collapse of our nation's population ends in 2020 and then we would have an increase in the number of population as the consequence of a TFR around the replacement rate and a relatively low migration rate. According to these projections, the population of Albania will continue to decline by 2025 and will then begin growth rates, albeit modest.

According to population projections, another phenomenon that is noticed is the increase in the old age index, which in 2055 is projected to be 26.1 percent. This means that in the future Albania will face the problem of aging of the population. Population aging has a negative impact on PAYG pension schemes. Figure No.5, refers to the Projections of group-ages through years

Figure 4

Migration Projections

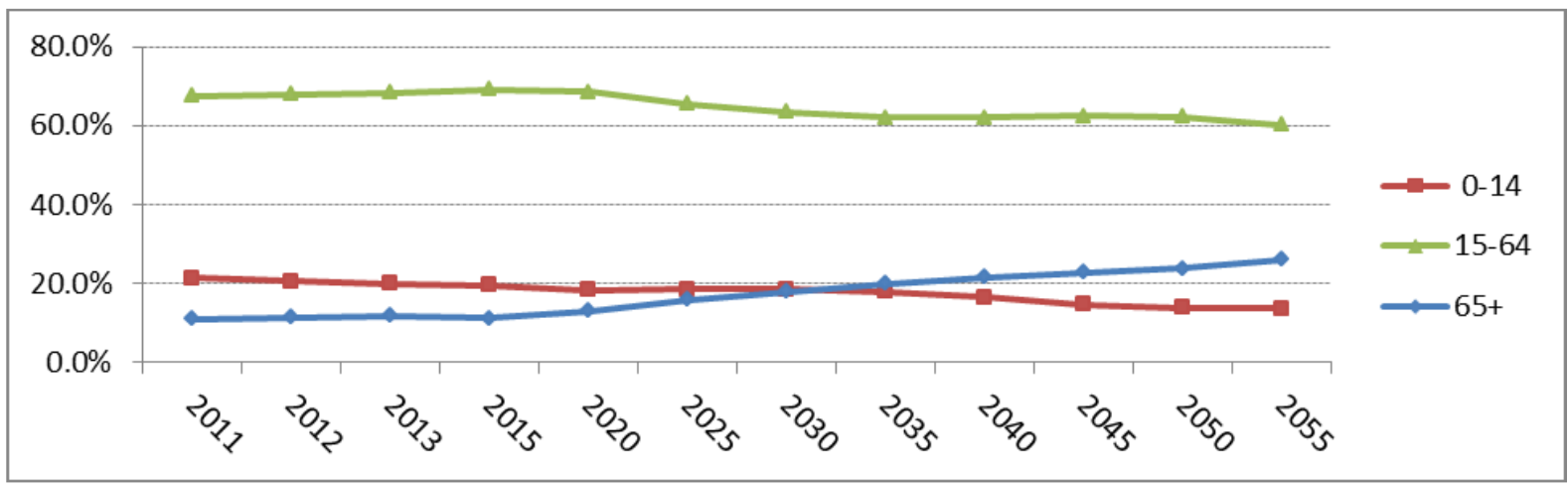

Source: Guxho (2014)

7 


\section{Some projections for economic indicators}

First, labor market data for the years 2013-2017 is presented in Table 3.

Table 3

Participation Scale in Labor Force

\begin{tabular}{cccccc}
\hline & 2013 & 2014 & 2015 & 2016 & 2017 \\
\hline $15-29$ & 38.7 & 41.9 & 44.5 & 45.7 & 45.6 \\
\hline $30-64$ & 71.1 & 72.3 & 74.5 & 76.1 & 77.0 \\
$15-64$ & 59.6 & 61.5 & 64.2 & 66.2 & 66.8 \\
$15+$ & 52.4 & 53.7 & 55.7 & 57.5 & 58.3 \\
\hline
\end{tabular}

Source: INSTAT (2017)

Second, the projections for the average participation rate in the labor force is made through the equations 1 and 2 (Fiche, 2017):

$$
\begin{gathered}
P R(\bar{a}, \underline{a}, t)=\sum_{a=\underline{a}}^{\bar{a}} \sum_{g=m, f} P R_{a, g}^{t} * p_{a, g}^{t} \\
p_{a, g}^{t}=\frac{p o p_{a, g}^{t}}{\sum_{a=\underline{a}}^{\bar{a}} \sum_{g=m, f} p o p_{a, g}^{t}}
\end{gathered}
$$

Where $\bar{a}_{\text {is }}$ the upper limit of group-age, $\underline{a}$ is the bottom limit of the group age, $g$ is sex, $t$ is time, $P R_{a, g}^{t}$ is the rate of participation in the labor force for this age group in year $t$, pop is population, $p$ is population structure.

Third, to calculate the number of contributors, there are used three hypotheses:

a) Low hypothesis, i.e. the unemployment rate decreases at slow rates, becoming $13 \%$ in 2025 and then kept constant. b) The average hypothesis, i.e. unemployment rate decreases at average rates and reaches $11.2 \%$ in 2025 and is then kept constant. c) The high hypothesis, i.e. unemployment rate decreases rapidly at 9.3 percent in 2025 and is then kept constant.

The labor market in Albania is characterized by a high degree of informality, expressed in two forms: the non-declaration of employed persons (more in rural areas than urban ones) and lower wage declaration, therefore, a reduction in social security contributions (mostly in urban areas). Currently, according to INSTAT (2017) there are about 1157 thousand people employed for 2016 and according to ISSH (2017) are 718.3 thousand contributors. So, around $63 \%$ of employed persons pay social security contributions. This ratio is maintained at $70 \%$ (considering the improvement of the informality situation) constant until the end of the forecast period.

The legal retirement age is thought to be 65 for men and 63 for women and remains unchanged throughout the period. The growth rate of_GDP is considered to be $3.8 \%$ for 2017, it is foreseen according Ministry of Finances (Albanian Government, 2017) to be $4 \%$ in 2020, and it is foreseen to be constant from 2020 and on.

The inflation rate is 1.3\% in 2017 and is foreseen to be constant at $2 \%$ from 2020 and on. The real wage growth is $-0.2 \%$ in 2017 and is foreseen to be constant at $3 \%$ from 2020 and on. As far as the indexation of pensions is concerned, the assumption is that 
this will be done with the inflation rate. Referring to the assumption of indexing the wages, they are indexed with nominal GDP growth.

\section{Pension and financial projections}

The baseline scenario used in this part of the study, refers to the most optimal scenario, which is considered the average one. All the calculations are based upon the average hypothesis of each above-mentioned projections. Table 4 refers to the performance in years of income and expenditure for pensions under the pure public pension scheme (The one that is still in implementation).

Table 4

Revenues and Expenditures According to Public Pension Scheme

\begin{tabular}{|c|c|c|c|c|c|}
\hline & 2020 & 2025 & 2030 & 2040 & 2050 \\
\hline $\begin{array}{l}\text { Total public pensions (rural +urban) /GDP } \\
\text { (\%) }\end{array}$ & 9.8 & 10 & 9.7 & 11.2 & 11.4 \\
\hline $\begin{array}{c}\text { Total revenues from contributions } \\
\text { (rural+urban) /GDP (\%) }\end{array}$ & 7.2 & 7.3 & 7.8 & 12.7 & 13.1 \\
\hline $\begin{array}{l}\text { Deficit (balance) of current pension } \\
\text { scheme (\%) }\end{array}$ & 2.6 & 2.7 & 1.9 & -1.5 & -1.7 \\
\hline
\end{tabular}

Source: Authors' work

The growth rate of expenditures is much higher than the rate of revenue growth (although increasing gradually), making the scheme more financially unstable. Consequently, the current deficit of the pension scheme will continue to deepen reaching the peak of 2025 with $2.7 \%$ of GDP. Then the deficit starts gradually decreasing, moving negatively at somehow between 2030 and 2040. Considering the fact that the pure public pension scheme has some problems and it cannot finance itself, before going in an inevitable crisis a new private scheme should be considered. In 2014, the Government has approved a new reform on pension, which considers two options:

The equations for calculation of the pension would be:

$$
P=P S+S h
$$

Where:

- $P$ is the monthly pension measure;

- PS is a social pension, the amount of which is no higher than the partial pension payment provided by the contributory scheme;

- $\quad$ Sh is an addendum whose value is $1 \%$ of the base value of the annual basis, which represents the ratio of the average contribution in the current year to the average contributions of previous years

Other elements should be considered regarding the age and so on. While the Private pension funds will continue to be based on the free will of the citizens to contribute to them.

According to the second option, the equation for calculation of the pension would be:

$$
\mathrm{P}=\frac{K a+F}{J m}
$$


Where:

- $\mathrm{P}$ is the pension measure; There is the aggregate amount of capital accumulated throughout the years when contributions are paid;

- $\mathrm{F}$ is the notional gain accumulated over the years because of the application of the national interest rate;

- Jm is the average life expectancy of the population at retirement age.

Thus, now of retirement, the aggregate amount of accumulated capital and "nonprofit" earnings are divided by the average life expectancy and are converted into an annuity, which is then converted into monthly pensions. This paradigmatic reform moves toward the system with a national account. This system works according to the Pay-As-You-Go principle, just like the current scheme, which means that current contributions are used to cover current benefit costs. However, the national system represents a substantial change compared to the current system. This is because this system is designed to imitate a private defined contribution system where the pension amount is determined by the history of individual contributions and their profit rate, but in this kind of system, the profit rate by contribution is defined by the government in national aspect, rather than the product of their investment in financial markets.

Figure 6

Projection of Balance in \% of GDP for Two Options of the New Pension Reform

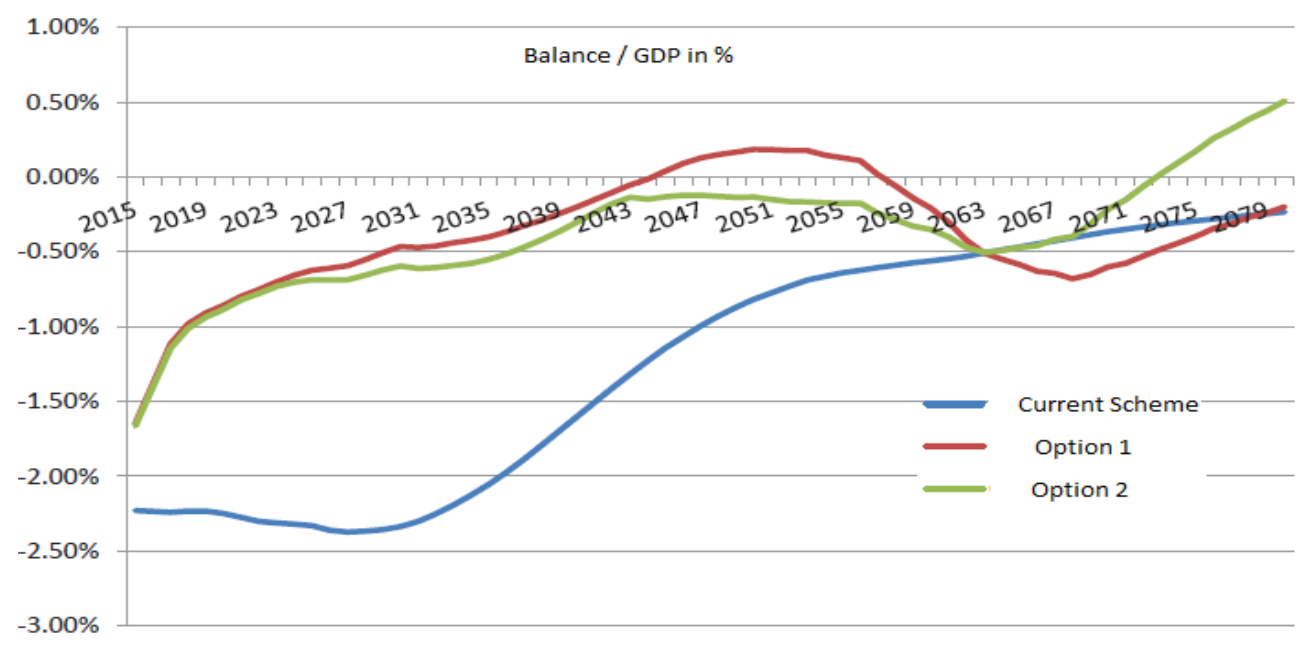

Source: Ministry of social wellbeing and youth (2014)

Referring to Figure No.6, the Option 2, compared with Option 1, guarantees higher benefits than the current scheme after 2035. Thus, under the Option 1, the actual deficit scheme, which represents the difference between the income from the contributions and total spending and does not include the cost of social pension, deepens from $2.2 \%$ of GDP to approximately $2.4 \%$ of GDP in 2027 . It then gradually began to decrease, falling to $1.5 \%$ GDP in 2041, to $1 \%$ of GDP in 2046 and remain at $0.5 \%$ of GDP after 2064. Under option 2, the deficit immediately falls from $1.6 \%$ of GDP in 2015 to $1 \%$ of GDP in 2018. The gradual decline of the deficit continues for the remaining period, falling below $0.5 \%$ of GDP for the period 2037-2074, the year in which the system passes into surplus. 


\section{Conclusion}

The basic motive for reforming the pension system in Albanian case, based on both theoretical and empirical results lies in the progress of the demographic trend in the future and the macroeconomic trends of the country.

Despite the reforms undertaken over the years, according to the study, it is emergent and necessary the transferring of the pension system from that PAYG to the system of multiple columns, where the special weight will also occupy the fully funded system.

1) Specifically, also based on the structure of the Albanian population, the recommendations regarding the application of the multi- pillars system are as below: The application of the first column, which includes all the elderly, regardless of whether they contribute or not, by providing them the vital minimum, regardless of whether they do not have the seniority needed to work for retirement benefits. Albania will go so towards the European countries' trends furning into one a more social and solid state in supporting the generations.

2) The introduction of the second column, which is the combination of the public scheme -pay as you go (current scheme based on solidarity between generations), which will guarantee a basic pension, and private scheme, where private companies will be selected and invested these funds in the financial market to enable growth of the amount of the contribution that will be distributed pensioners on the basis of contributions that have been paid over the years.

3) Development of the third column, that is, the current private scheme for all persons wishing to benefit from higher pensions than normal in retirement age

The new governmental pension reforms offer two options for reform. Option 1 focuses on improving parameters of current systems. Option 2 proposes a paradigmatic reform by being shifted towards the system with a niche account. Both options focus on tightening the connection between contributions and benefits by encouraging citizens to become part of the scheme and contribute to their real wage. Consequently, both proposed options bring one deficit reduction as well as higher benefits for citizens. By 2030, both options have almost the same performance in reducing the deficit. After this year Option 1 results more effective than Option 2 in reducing the deficit by giving a deficit of almost 1\% Lower GDP at the end of the forecast period..

\section{References}

1. Albanian Government (2017), "Economic and fiscal program 2017-2019", available at: http://www.qbz.gov.al/botime/fletore zyrtare/2016/PDF-2016/261-2016.pdf (17 August 2018)

2. Blake, D. (1992), Modeling pension fund investment behavior, Routledge, London.

3. Baldwin, B. (2009), "Research Study on the Canadian Retirement Income System", Baldwin Consulting, Canada, available at: https://www.fin.gov.on.ca/en/consultations/pension/dec09report.pdf/ (17 August 2018)

4. Centre for Research and Policy Making (2005), "Pension System Reform in Macedonia", Occasional Paper No. 7, available at: http://www.crpm.org.mk/wpcontent/uploads/2012/03/Occasional-Paper-N7.pdf/ (17 August 2018)

5. Deacon, B., Stubbs, P. (2005), "The Making of Social Policy in South-Eastern Europe: Theories, Methods, Politics, in Kuhnle, S. (Ed.) Social Policy development in South Eastern Europe: outside influences and domestic forces, Bergen, Stein Rokkan Centre for Social Studies, Norway, pp. 27-52. 
6. Eurostat (2013), "European Social statistics", available at: http://ec.europa.eu/eurostat/web/products-pocketbooks/-/KS-FP-13-001 (17 August 2018)

7. Fiche, C. (2017), "Pension Projections exercise 2018", Germany, available at: https://ec.europa.eu/info/sites/info/files/economyfinance/final_country fiche_de.pdf/ (17 August 2018)

8. Guxho, A. (2014), "Pension scheme in Albania and actuarial forecasting", Doctoral Dissertation, University of Tirana.

9. Holzmann, R., MacKellar L., Repansek J. (2008), "Pension Reform in Southeastern Europe Linking to Labor and Financial Market Reforms", available at: https://openknowledge.worldbank.org/handle/10986/2587/ (17 August 2018)

10. ILO (201 1), "ILO estimates and projections of the economically active population 19902020", available at: http://laborsta.ilo.org/applv8/data/EAPEP/v6/ILO_EAPEP_methodology_2011.pdf (17 August 2018)

11. IOM - Country profile Albania (2017), available at: https://www.albania.iom.int/albania/ (17 August 2018)

12. INSTAT (2011), "Census 2011 ", available at: http://www.instat.gov.al/media/3058/main_results_population_and_housing_census 2011.pdf/ (17 August 2018)

13. INSTAT (2017), available at: http://www.instat.gov.al/al/temat/tregu-i-pun\%C3\%ABsdhe-arsimi/pun\%C3\%ABsimi-dhe-papun\%C3\%ABsia/\#tab2/ (17 August 2018)

14. INSTAT (2018), available at: http://www.instat.gov.al/al/temat/treguesit-demografik\%C3\%AB-dhesocial\%C3\%AB/popullsia/publikimet/2018/popullsia-e-shqip\%C3\%ABris\%C3\%AB-1janar-2018/ (17 August 2018)

15. ISSH (2017), available at: http://www.issh.gov.al/wp-content/uploads/2014/02/issh-pertu-pare-shaip-ang.pdf (17 August 2018)

16. Lama, A. (2008), "Social inclusion and social protection in Albania", available at: http://ec.europa.eu/social/BlobServlet?docld=4446\&langld=en (17 August 2018)

17. Ministry of social wellbeing and youth (2014), "Document of Pension policy", available at:

http://www.monitor.al/multimedia/Dokumenti\%20i\%20Politikave\%20te\%20Pensioneve. pdf (17 August 2018)

18. Schwarz, A. (2006), "Pension System Reforms", The World Bank, available at: http://siteresources.worldbank.org/SOCIALPROTECTION/Resources/SP-Discussionpapers/Pensions-DP/0608.pdf/ (17 August 2018)

19. Xhumari, M. (2000), "Welfare programs for unemployment income in Albania", avaiable at:

http://repository.erstestiftung.org/homes/repository/300\%20Social\%20sciences/305\%20 Social\%20Groups/305.2\%20Age\%20groups/305.26\%20Persons\%20in\%20late\%20adultho od/Social\%20research_demography\%20and\%20ageing/12_Xhumari.pdf/

(17 August 2018) 


\section{About the authors}

Olgerta Idrizi, Ph.D Candidate, is an Assistant Professor at the Faculty of Economics, Mediterranean University, Tirana, Albania, Department of Informatics and Scientific Education. She is a PHD student in Statistic field, "Actuarial Methods on Life Insurance and Pension Plans on Millenian Generation" at the Faculty of Economics, University of Tirana. Research activity of Idrizi is focused on: Statistic, Database, Information Systems etc. She has an experience as reporting Analyst on several Prestige Companies in Tirana Albania. She is author of several, articles and scientific presentations in national and international forums. The author can be contacted at olgerta.idrizi@hotmail.com.

Besa Shahini, Prof.Dr. is a Professor at the Faculty of Economics, University of Tirana, Department of Applied Statistics and Informatics. She received a PhD in Statistic field at the Faculty of Economic. Her main research interests are statistic, simulation modelling etc. She is actively engaged in number of science projects and national projects. Besa Shahini published several scientific papers in international and national journals and participated in many scientific international conferences.

The author can be contacted at besashahini@feut.edu.al. 